\title{
Review
}

\section{Genome-wide analysis of microRNA and mRNA expression signatures in cancer}

\author{
Ming-hui LI, Sheng-bo FU, Hua-sheng XIAO*
}

National Engineering Center for Biochip at Shanghai, Shanghai Biotechnology Corporation, Shanghai 201203, China

\begin{abstract}
Cancer is an extremely diverse and complex disease that results from various genetic and epigenetic changes such as DNA copy-number variations, mutations, and aberrant mRNA and/or protein expression caused by abnormal transcriptional regulation. The expression profiles of certain microRNAs (miRNAs) and messenger RNAs (mRNAs) are closely related to cancer progression stages. In the past few decades, DNA microarray and next-generation sequencing techniques have been widely applied to identify miRNA and mRNA signatures for cancers on a genome-wide scale and have provided meaningful insights into cancer diagnosis, prognosis and personalized medicine. In this review, we summarize the progress in genome-wide analysis of miRNAs and mRNAs as cancer biomarkers, highlighting their diagnostic and prognostic roles.
\end{abstract}

Keywords: miRNA; mRNA; biomarker; gene signature; cancer; genome-wide analysis

Acta Pharmacologica Sinica (2015) 36: 1200-1211; doi: 10.1038/aps.2015.67; published online 24 Aug 2015

\section{Introduction}

Cancer is the term used for a diverse collection of diseases characterized by uncontrolled cell growth caused by genetic and/or epigenetic disorders and results in aberrant gene function and/or expression. Cancer is one of the leading causes of death in developed countries and is projected to become a major cause of death worldwide ${ }^{[1]}$. Biomarkers play important roles in cancer diagnosis, prognosis and therapy. Currently, several classes of tumor biomarkers are being exploited, including DNA-based, RNA-based, protein-based and epigenetic-based biomarkers. The DNA-level aberrations in cancer comprise single nucleotide variants (SNVs), small InDels (small insertions or deletions), structural variants (SVs) and copy number variants $(\mathrm{CNVs})^{[2]}$. RNA-based biomarkers include overexpressed or underexpressed mRNAs, miRNAs and noncoding RNAs. Protein markers include glycoproteins such as AFP (alpha-fetoprotein, a marker for liver cancer), CA125 (for ovarian cancer), and tumor antigens such as PSA (prostate-specific antigen, for prostate cancer) ${ }^{[3]}$ and CEA (carcinoembryonic antigen, for colon cancer).

mRNAs, miRNAs, and other noncoding RNA are major components of the gene expression network and cooperate to affect biological processes. These molecules play important

*To whom correspondence should be addressed.

E-mail huasheng_xiao@shbiochip.com

Received 2015-03-16 Accepted 2015-06-22 roles in cell-cycle control, cell proliferation, apoptosis, differentiation, metabolism, contact inhibition, metastasis and posttranscriptional gene regulation during the development of cancer. In recent years, applications of DNA-microarray and next generation sequencing (NGS) techniques have enabled simultaneous analysis of the expression profiles of tens of thousands of genes in various tumor samples, including serum, plasma, urine, and formalin-fixed paraffin-embedded (FFPE) or biopsy tissues. The transcription-level changes in mRNAs, miRNAs, and other noncoding RNAs detected by high-throughput approaches provide novel insights into the identification of RNA-level cancer biomarkers. Moreover, in combination with novel computational strategies, recent genome-wide studies have unveiled the intrinsic relationships among dysregulated miRNA-mRNA interactions in cancers and explored their roles as biomarkers. In this review, we discuss the discovery and utilization of miRNA and mRNA biomarkers for cancer using genome-wide approaches, with emphasis on their roles in cancer diagnosis, prognosis and therapeutic applications. We also summarize the progress of the integrated genome-wide analysis of miRNA and mRNA in cancer.

\section{miRNA signatures in cancer}

Short (approximately 22 nucleotides) noncoding miRNAs are a class of small regulatory RNA molecules discovered in $1993^{[4]}$. They trigger mRNA degradation or repression of translation 
via the 6-8 base pair "seed region" complementarily at the end of the miRNA-mRNA heteroduplex ${ }^{[5]}$. One miRNA may regulate hundreds of genes, and it has been estimated that more than $50 \%$ of mRNAs are regulated by miRNAs in mammalian genomes ${ }^{[6]}$. Thus, altered miRNA expression may affect a variety of cellular processes and diseases, and many studies have shown that miRNAs play important roles in the initiation, progression and invasion of human cancer ${ }^{[7,8]}$. miRNAs can act as either oncogenes or tumor suppressors. For example, the miR-17-92 polycistron, which has been found to be amplified in human B-cell lymphomas, was the first miRNA (cluster) characterized with potent oncogenic activity $^{[9]}$. Many other miRNAs have also been identified as promoters or suppressors of oncogenesis by regulating specific oncogenic or tumor-suppressing pathways ${ }^{[10]}$. Increasing amounts of evidence have demonstrated that miRNAs exhibit spatiotemporal expression patterns and that many miRNAs are differentially expressed in cancerous tissues compared with adjacent normal tissues or at different stages of cancer progression $^{[11,12]}$. The strong relationships between miRNA expression profiles and cancer progress are supported by many studies that profiled the miRNA patterns in various cancer types and inferred the value of miRNAs in diagnostic and prognostic applications ${ }^{[13]}$.

\section{miRNAs/panels as diagnostic markers for cancer}

miRNAs are promising biomarkers for cancer diagnosis. The current diagnostic miRNAs and panels for cancer biomarker are listed in Table 1 . Yanaihara et $a l^{[14]}$ identified unique profiles of 43 miRNAs that could discriminate between lung cancer and noncancerous tissues by analyzing 104 pairs of primary lung cancers and noncancerous lung tissue by miRNA microarray analysis. The panel of miR-375, miR-424 and miR92a distinguishes carcinomas from adenomas in colorectal cancer $^{[15]}$. In a large-scale miRNA expression analysis of 540 samples of six solid tumors (lung, breast, stomach, prostate, colon, and pancreas), a group of 43 miRNAs were found to be dysregulated compared with matched normal tissues ${ }^{[16]}$. The study of the miRNA profiles of archived FFPE samples of papillary thyroid carcinoma (PTC) first demonstrated the utilization of FFPE samples as appropriate resources for miRNA microarray analysis and identified miR-21, miR-31, miR-221 and miR-222 as potential markers of PTC ${ }^{[17]}$. Circulating miRNAs are another source of cancer biomarkers. A microRNA panel (miR-122, miR-192, miR-21, miR-223, miR-26a, miR27a and miR-801) in plasma was identified using an miRNA microarray and provides high diagnostic accuracy for hepatocellular carcinoma (HCC) diagnosis ${ }^{[18]}$. In our previous published study, three miRNAs (miR-187*, miR-371-5p and miR378) were significantly upregulated in sera from gastric cancer (GC) patients, and miR-378 was validated as a noninvasive biomarker in GC detection ${ }^{[19]}$.

In addition to microarray technology, small RNA sequencing has also been applied to biomarker identification. For example, using Solexa sequencing ${ }^{[20]}, 25$ serum miRNAs were identified to be upregulated in esophageal squamous cell car- cinoma (ESCC) patients compared with the controls. RT-qPCR analysis also confirmed a panel of 7 serum miRNAs (miR10a, miR-22, miR-100, miR-148b, miR-223, miR-133a, and miR127-3p) as ESCC biomarkers. Chen et al ${ }^{[21]}$ applied NGS and discovered elevated expression levels of miR-25 and miR-223 in the serum, which are blood-based biomarkers of non-small cell lung carcinoma (NSCLC). Using small RNA sequencing, miRNA biomarkers have been identified from human tissue, blood and FFPE samples in a wide range of tumor types, such as gastric cancer ${ }^{[22]}$, hepatocarcinoma ${ }^{[23]}$, breast cancer ${ }^{[24,25]}$, and prostate cancer ${ }^{[26]}$.

Different tumor subtypes may exhibit distinct miRNA expression signatures that can be used as diagnostic miRNA biomarkers to classify tumor subtypes ${ }^{[13]}$. The cure rate of cancer patients can be increased if the cancer subtype is correctly classified and treated with appropriate drugs and therapeutic methods. miRNA expression signatures have been used to classify subtypes in acute myeloid leukemia (AML) and leu$\operatorname{kemia}^{[27,28]}$. Downregulation of miR-34a, let-7b, miR-106a, and miR-141 and upregulation of miR-301 and miR-452 was found in prostate cancer and used to discriminate among subtypes of prostate cancer ${ }^{[29]}$. In HCC, a 7-miRNA signature panel (miR16, miR-122, miR-21, miR-223, miR-25, miR-375, and let-7f) was recently reported to successfully diagnose patients with HCC, patients with hepatitis $B$, and healthy individuals ${ }^{[23,}$ ${ }^{30]}$. Gilad et al reported a single assay to classify the four main types of lung cancer, carcinoid, SCLC, and squamous and nonsquamous NSCLC, using the expression of eight miRNAs (miR-7, miR-21, miR-29b, miR-106a, miR-125a-5p, miR-129-3p, miR-205, miR-375) $)^{[31]}$.

\section{miRNAs/panels as prognostic biomarkers for cancer}

miRNA expression profiles can also serve as biomarkers of prognosis. Table 2 summarizes the prognostic miRNAs from recent studies identified by genome-wide analysis. Yanaihara et $a l^{[14]}$ showed that lung adenocarcinoma patients with either high miR-155 or reduced let-7a-2 expression had poor survival. High miR-21 expression was associated with poor survival and therapeutic outcome in colon adenocarcinoma ${ }^{[73]}$. In HCC, the loss of miR-122 expression is linked to cancer progression and gain of metastatic properties ${ }^{[74]}$. Lower expression of let-7 is associated with significantly shorter survival in patients with lung cancer after resection ${ }^{[75]}$. The loss of miR335 and miR-126 expression occurs in the majority of primary breast tumors in patients whose relapse is associated with poor distal-metastasis-free survival ${ }^{[76]}$. The study of miRNAs as cancer biomarkers may promote the application of miRNAbased tests as an alternative to mRNA/protein expression for prognosis assessment.

\section{miRNA/panels as predictive biomarkers for cancer}

miRNA can serve as predictive biomarkers of tumor recurrence and/or metastasis. miR-126 has been shown to regulate endothelial cell recruitment to metastatic breast cancer cells through coordinated targeting of IGFBP2, PITPNC1 and MERTK, and miR-126 might serve as an 
Table 1. Summary of diagnostic miRNAs/panel.

\begin{tabular}{|c|c|c|}
\hline Cancer & Sample type & Diagnostic miRNAs/panel \\
\hline \multirow[t]{2}{*}{ Gastric cancer } & Tissue/FFPE & $\operatorname{miR}-106 a \uparrow^{[32]} ; \mathrm{miR}-31 \downarrow^{[33]}$ \\
\hline & Serum/Plasma/Whole Blood & 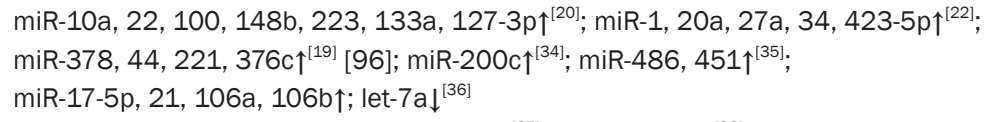 \\
\hline \multirow[t]{2}{*}{ Pancreatic cancer } & Tissue/FFPE & $\begin{array}{l}\operatorname{miR}-452,105,127,518 a-2,187,30 a-3 p \uparrow^{[37]} ; \operatorname{miR}-21,155 \uparrow^{[38]} \\
\operatorname{miR}-21,221,222, \text { let-7a } \uparrow^{[39]}\end{array}$ \\
\hline & Serum/Plasma/Whole Blood & $\operatorname{miR}-21,210,155,196 a \uparrow^{[40-42]}$ \\
\hline \multirow[t]{2}{*}{ Breast cancer } & Tissue/FFPE & 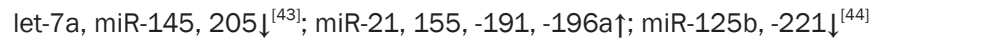 \\
\hline & Serum/Plasma/Whole Blood & $\operatorname{miR}-373,520 c \uparrow^{[45]} ; \mathrm{miR}-10 b, 22 \uparrow^{[135,136]}$ \\
\hline \multirow[t]{2}{*}{ Hepatocellular carcinoma } & Tissue & let-7 family $\downarrow^{[46]}$ \\
\hline & Serum/Plasma/Whole Blood & $\begin{array}{l}\operatorname{miR}-500 \uparrow^{[47]} ; \operatorname{miR}-1,25,92 a, 206,375 \text {, let- } 7 f \uparrow^{[23]} ; \operatorname{miR}-21,122,223 \uparrow^{[48,49]} \\
\operatorname{miR}-122 \uparrow^{[139]} ; \operatorname{miR}-885-5 p \uparrow^{[50]} ; \operatorname{miR}-16 \downarrow^{[51]}\end{array}$ \\
\hline \multirow[t]{2}{*}{ Lung cancer } & Tissue/FFPE & miR-21, 205 $5^{[52]}$; let 7 family $\downarrow^{[53]} ;$ miR-17-miR-92 $\uparrow^{[54]}$ \\
\hline & Serum/Plasma/Whole Blood & $\begin{array}{l}\operatorname{miR}-25,223 \uparrow^{[21]} ; \text { miR-10b, } 155 \uparrow^{[55]} ; \text { miR-17-3p, 21, 106a, 146, 155, 191, } 192, \\
\text { 203, 205, 210, 212, 214 } \uparrow^{[56,57]} \text {; let-7d, let-7f, miR-223, 383, 192, 30e-5p, 301, } \\
\text { 572, 20b, 345 } \downarrow^{[58]}\end{array}$ \\
\hline \multirow[t]{2}{*}{ Prostate cancer } & Tissue/FFPE & 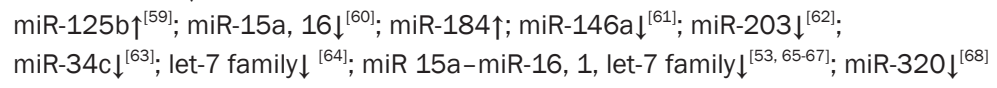 \\
\hline & Serum/Plasma/Whole Blood & 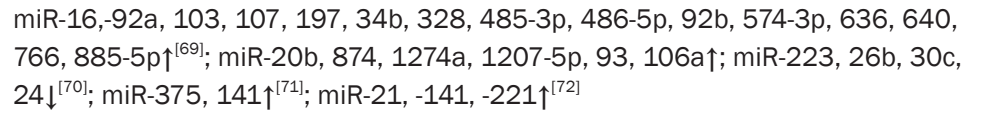 \\
\hline
\end{tabular}

Table 2. Summary of prognostic miRNAs/panel.

\begin{tabular}{|c|c|c|}
\hline Cancer & Sample type & Prognostic miRNAs/panel \\
\hline Gastric cancer & Tissue/FFPE & 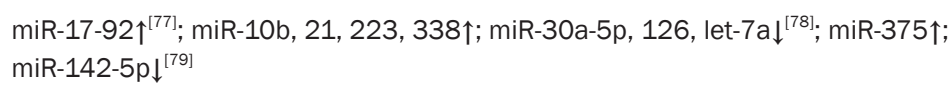 \\
\hline Pancreatic cancer & $\begin{array}{l}\text { FFPE } \\
\text { Serum }\end{array}$ & $\begin{array}{l}\operatorname{miR}-200 c \downarrow^{[80]} \\
\operatorname{miR}-196 a \uparrow^{[81]}\end{array}$ \\
\hline Breast cancer & $\begin{array}{l}\text { Tissue/FFPE } \\
\text { Serum/Whole Blood }\end{array}$ & $\begin{array}{l}\operatorname{miR}-31,335^{[82,83]} ; \operatorname{miR}-21 \uparrow^{[84]} \\
\operatorname{miR}-155 \uparrow^{[85]} ; \text { miR-10b, 34a/c, } 155^{[86-89]} ; \operatorname{miR}-21^{[90]} ; \operatorname{miR}-21,10 b \uparrow^{[91]} ; \text { let- } 7 a \downarrow^{[46]}\end{array}$ \\
\hline Lung cancer & $\begin{array}{l}\text { Tissue/FFPE } \\
\text { Serum/Plasma }\end{array}$ & $\begin{array}{l}\operatorname{miR}-16 \uparrow^{[92]} \\
\operatorname{miR}-486,30 d \uparrow ; m i R-1,499^{[93]} ; \operatorname{miR}-10 b \uparrow^{[55]} ; \text { let- } 7 f, \operatorname{miR}-30 e-3 p \uparrow^{[58]}\end{array}$ \\
\hline Cervical cancer & Tissue/FFPE & $\operatorname{miR}-9,200 a^{[94]}$ \\
\hline Ovarian cancer & $\begin{array}{l}\text { Tissue/FFPE } \\
\text { Serum }\end{array}$ & $\begin{array}{l}\text { miR-223个; miR-9 } \downarrow^{[95]} \text {; miR-200a, 200b, 429 } \downarrow^{[96]} ; \operatorname{miR}-23 a, 27 a \uparrow^{[97]} ; \operatorname{miR}-29 b \uparrow^{[98]} \text {; } \\
\text { miR-21, 141, 200a, 200c, 200b, 203, 205, } 214 \uparrow^{[99]}\end{array}$ \\
\hline Prostate cancer & $\begin{array}{l}\text { Tissue/FFPE } \\
\text { Serum }\end{array}$ & $\begin{array}{l}\operatorname{miR}-184 \uparrow^{[61]} ; \operatorname{miR}-34 c \downarrow^{[63]} ; \operatorname{miR}-221 \downarrow^{[100]} \\
\operatorname{miR}-100,125 b, 141,143,296 \uparrow^{[101]} ; \operatorname{miR}-24 \downarrow^{[70]} ; \operatorname{miR}-375,141 \uparrow^{[71]} ; \operatorname{miR}-21 \uparrow^{[102]} \\
\operatorname{miR}-34 a / c \downarrow^{[87,88,103]}\end{array}$ \\
\hline
\end{tabular}

efficient biomarker to forecast cancer metastasis ${ }^{[104]}$. miR-221 is progressively downregulated in aggressive prostate cancer, lymph node metastases, and clinical recurrence and serves as a biomarker predicting the progression and recurrence in highrisk prostate cancer ${ }^{[100]}$.

Predictive miRNA biomarkers can also predict a patient's response to therapy and aid in treatment decisions. For example, miR-21 expression was significantly increased in platinum-based chemotherapy-resistant NSCLC patients, and increased miR-21 expression was associated with shorter disease-free survival ${ }^{[105,106]}$. Forty-one nasopharyngeal carcinoma (NPC) patients were analyzed before and after radiotherapy and showed that expression of miR-BART7 and miR-BART13 was abolished after treatment, indicating that these two Epstein-Barr virus (EBV) miRNAs are useful predictive biomarkers of NPC treatment efficacy. miR-107 and miR-99a-3p were also identified as predictive markers for chemotherapy response in advanced colorectal cancer ${ }^{[107]}$. An miRNA panel comprising miR-1290, miR-196b, and miR-135a* has been used to predict responses to platinum-based doublet chemotherapy in patients with lung adenocarcinoma ${ }^{[108]}$.

\section{mRNA profiles as cancer signatures}

mRNA profiling has shown that mRNA expression is also 
associated with cancer progression and identified effective cancer biomarkers. Aberrant expression of oncogenes (such as KRAS and MYC) and tumor suppressor genes (TSGs) (such as APC, BRAF, TP53, etc) are often correlated with cancer development, which might be caused by chromosomal instability, accumulation of mutations, CNVs or DNA methylation modifications. Moreover, all steps of mRNA biogenesis might be affected during cancer progression, from transcription, splicing, post-transcription regulation, and translation to mRNA stability control. For example, different isoforms of a gene can display opposite functions in tumor generation, such as the two transcript variants of BCL-x, which can serve as inhibitors or activators of apoptosis, respectively ${ }^{[109]}$. Given the complexity of cancer progression and transcriptome composition, genome-wide profiles have been widely used to obtain a whole transcriptome profile from tumor specimens and provide comprehensive and accurate information regarding mRNA expression that might serve as cancer signatures in diagnosis and prognosis, especially for subtype classifications.

\section{mRNA profiles as diagnostic cancer markers}

The first study using a microarray technique to explore global mRNA expression trends and identify tumor classifiers was reported by Golub et al ${ }^{[110]}$ They classified acute myeloid leukemia (AML) and acute lymphoblastic leukemia (ALL) using the Affymetrix gene microarray with 6817 human genes. A 50 -gene panel was generated from analysis of 38 bone marrow samples (11 AML, 27 ALL) and verified to have high power in classifying AML and ALL. Since then, genome-wide microarray analysis has been widely utilized in identifying numerous diagnostic biomarkers in lung cancer ${ }^{[111]}$, gastric cancer ${ }^{[112]}$, prostate cancer $^{[113]}$, and other types of cancer. Different types of cancer exhibit distinctive expression profiles; for example, in epithelial ovarian cancer (EOC) there is low expression of p53, BCL-2, BAX, EGFR and HER2, and overexpression of ASAP1 ${ }^{[114-117]}$. The expression of IKBK $\beta$, CREBBP, WNT10B, PRDX6, ITGAV, and IFNAR1 was found to be associated with hepatic carcinogenesis ${ }^{[118]}$. Other mRNA markers, including ELA2, MPO, STAT4, and FUS, were upregulated, and AXIN2, LEF1, SFRP2 were downregulated in AML ${ }^{[119-121]}$. However, some genes might be related to other forms of cancer. The eIF4E gene is overexpressed in cancers of the breast, head and neck, bladder, colon, lung, and prostate and is related to reduced patient survival ${ }^{[122-126]}$. Cancer development has also been shown to be linked to alternative splicing ${ }^{[127]}$. For example, a nonsense mutation in exon 18 of the tumor-suppressor BRCA1 gene, a well-known marker of breast and ovarian cancers, affects splicing and causes exon skipping ${ }^{[128]}$. Genomewide studies have identified a large number of cancer-specific alternative splicing events or fusion proteins, which are ideal diagnostic markers and therapeutic targets ${ }^{[129-131]}$.

In 2000, Perou and colleagues reported a new method to classify breast cancer by gene expression profiling ${ }^{[132]}$ and started to use gene expression microarrays for the diagnosis of breast and other cancers ${ }^{[133,134]}$. Colorectal cancer (CRC) subtyping has also been addressed using genome-wide gene expression profiling in large-scale patient samples ${ }^{[135]}$ (Table 3). ALL is a heterogeneous disease with more than 12 subtypes. A 62-gene classifier was created in white children's samples for subtype classification and validated on a completely independent set of 100 Chinese samples ${ }^{[134]}$. Breast cancer can also be classified into different subtypes using miRNA and mRNA expression data at The Cancer Genome Atlas (TCGA) database $^{[136]}$.

NGS has also been used to analyze mRNA biomarkers in cancers. For example, Sinicropi et al applied RNA-seq using FFPE samples to profile genome-wide mRNA expression in 136 breast cancer patients and identified 32 mRNAs that can serve as breast cancer biomarkers, indicating that RNA-Seq can provide a practical, sensitive and precise platform for genome-wide biomarker discovery in FFPE tissue. Similarly, RNA-seq has been applied to study biomarkers in hepatocellular carcinoma ${ }^{[137]}$, colorectal cancer $^{[138]}$, B-cell lymphoma ${ }^{[139]}$, melanoma ${ }^{[140]}$, and prostate cancer $^{[141]}$. RNA-seq has also been used to analyze alternative splicing associated in lung cancer ${ }^{[142]}$.

\section{mRNA profiles as prognostic cancer markers}

The expression status of estrogen receptors (ER) and HER2/ NEU (ERBB2) has been used in the prognosis of breast cancer. Different tumor types exhibit distinct gene expression signatures that can be used to sub-classify a certain cancer into prognostic groups (Table 3). For example, CRC subtypes can be classified using genome-wide gene expression profiling, and mRNA biomarkers can also be used for the prognosis and prediction of $\mathrm{CRC}^{[143,144]}$. One hundred fifteen gene signatures were identified through gene expression profiling of 68 ovarian cancer patients ${ }^{[145]}$. Platelet-derived growth factors (PDGFs) and their receptors (PDGFRs) are overexpressed in various cancers, and their expression levels correlate with tumor growth, invasion and prognosis. PDGF and PDGFR have been used as prognostic indicators in several carcinomas [146, 147]. Mantle cell lymphoma (MCL) is an aggressive form of non-Hodgkin lymphoma. Kridel et al discovered recurrent mutations in NOTCH1 by performing whole transcriptome sequencing on 18 primary-tissue MCL samples and 2 cell lines ${ }^{[148]}$. In an independent pool of samples, they also verified that $12 \%$ of clinical samples and $20 \%$ of cell lines showed NOTCH1 mutations, which were associated with poor overall survival. Brodtkorb et al found that 6 of the NF-kB pathway genes were significantly associated with the transformation of follicular lymphoma ${ }^{[149]}$. Clearly, genome-wide approaches have been widely applied in cancer research and have supplied informative insights into cancer prognosis.

\section{Clinical applications of genome-wide mRNA biomarkers}

Some diagnostic and prognostic microarrays have been developed and clinically applied. Breast cancer is the most frequently diagnosed cancer in women, accounting for approximately $30 \%$ of all cancers diagnosed and approximately $16 \%$ of all cancer-caused deaths ${ }^{[150,151]}$. The MammaPrint ${ }^{\mathrm{TM}}$ prognostic microarray provides a 70-gene expression profile that can be used to guide the treatment and prognostication 
Table 3. mRNA signature to classify cancer subtypes.

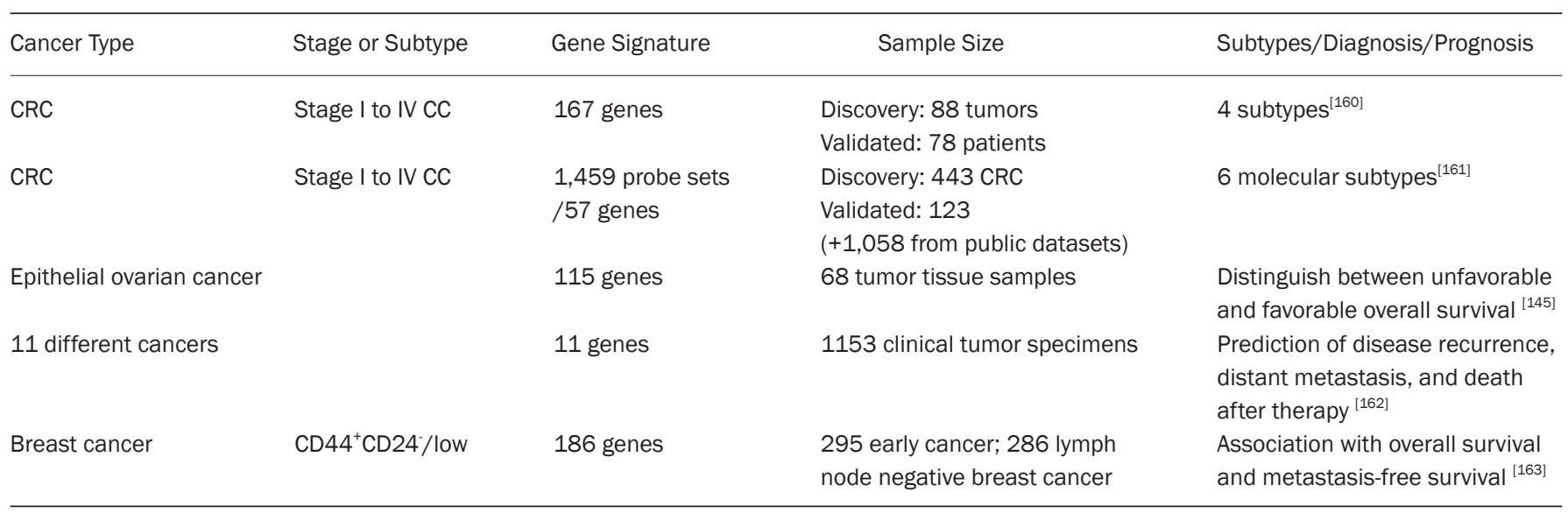

of breast. MammaPrint ${ }^{\mathrm{TM}}$ was developed on the Agilent platform and provides a poor prognosis readout, which consists of genes regulating cell cycle, invasion, metastasis and angiogenesis in patients who are lymph node negative at diagnosis ${ }^{[152,}$ 153]. An 18-gene signature for vascular invasion that is associated with aggressive features and reduced survival in breast cancer has been reported recently. By utilizing and compiling 11 open-access gene expression datasets from 2423 breast cancer patients, this 18-gene panel showed consistent associations with tumor grades, hormone receptor negativity, HER2 positivity, a basal-like phenotype, and reduced patient survival. Similarly, a 21-gene expression profile on Oncotype DXTM was used to guide the treatment and prognostication of breast cancer $^{[154]}$. Other commercially available microarray-based prognostic assays for breast cancer include PAM50 (ROR-S), the Breast Cancer Index, and EndoPredict ${ }^{[155]}$.

Several assays have been applied in colon cancer diagnosis. The Oncotype DX colon cancer assay uses a 12-gene signature and was validated in more than 1800 patients from four adjuvant trials ${ }^{[156]}$. The coloprint $(\mathrm{CP})$ assay is based on an 18-gene signature $^{[157]}$ and has been validated to contain prognostic genomic signatures for patients with stage II colon cancer ${ }^{[158]}$. The ColonSentry ${ }^{\mathrm{TM}} \mathrm{mRNA}$ expression panel is a patientfriendly test identifying 7 mRNA markers expressed in whole blood to diagnose colorectal cancer ${ }^{[159]}$.

\section{Integrated analysis of miRNAs and mRNAs in cancer}

Genome-wide gene expression profiling using microarray and deep sequencing technologies has significantly driven the discovery of cancer biomarkers. In addition to the expression signature of either miRNA or mRNA in a single type of cancer, many studies have applied integrated analyses of genomewide mRNA and miRNA expression signatures in cancers.

Using Agilent miRNA microarrays and Affymetrix wholegenome expression microarrays, we have identified differentially expressed miRNAs and mRNAs in HCPT-resistant and 10-hydroxycamptothecin (HCPT)-sensitive gastric cancer cells in a study of human gastric adenocarcinoma cell line responses to HCPT treatment ${ }^{[164]}$. Moreover, by integrating
miRNA target prediction, Gene Ontology (GO) analysis and pathway enrichment, we illustrated the genes and pathways related to carcinogenesis or chemoresponse, such as chemoresistant genes, drug metabolism-associated pathways (cytochrome P450, etc) and cell apoptosis-related pathways (S1P signaling pathway, etc). This study also reported coregulated miRNA-mRNA interactions in response to HCPT, such as the tumor suppressor gene BTG2 in gastric cancer cells, which was targeted by upregulated let-7g, miR-98, and miR-132 in HCPT-resistant cells. We found that approximately $1.3 \%$ of the predicted miRNA targets formed reciprocal "up-down" or "down-up" expression relationships with miRNAs, suggesting that the modulation of miRNA-mRNA interactions could be promising biomarkers for cancers.

Integrated expression analysis of miRNAs and mRNAs using microarray technology have revealed signatures implicated in ovarian cancer ${ }^{[165,166]}$, breast cancer ${ }^{[167-171]}$, metastatic osteosarcoma $^{[172]}$, gastric cancer ${ }^{[173,174]}$, pancreatic cancer ${ }^{[175]}$, oral squamous cell carcinoma ${ }^{[176]}$, lung cancer ${ }^{[177-179]}$, prostate cancer $^{[180,181]}$, follicular thyroid tumors ${ }^{[182]}$, retinoblastoma ${ }^{[183]}$, etc. The miRNA/mRNA interactome not only includes the interactions between an miRNA and its targets but also comprises the TF-miRNA network. For example, Barh et al observed upregulation of HMGA1, E2F6, IRF1, and TFDP1 and downregulation of SUV39H1, RBL1, and HNRPD, all of which are transcription factors, in blood samples of lung adenocarcinoma and squamous cell carcinoma NSCLC subtypes. The study also reported that HMGA1 and TFDP1 play vital roles in the miRNA-TF-miRNA interaction in the molecular mechanisms of tumor genesis.

To discover the potential oncogenic or tumor suppressive miRNA and mRNAs in carcinomas of the bladder, kidney and testis ${ }^{[184]}$, deep sequencing technology was used to profile aberrant miRNA and mRNA expressions at the systems level and revealed common hallmarks of human cancers including miRNAs and mRNAs that are involved in cell adhesion processes, p53 signaling, calcium signaling, ECM-receptor and cell cycle pathways, DNA repair and replication processes as well as immune and inflammatory response processes ${ }^{[182]}$. 
Furthermore, the authors also studied the correlation between each miRNA and its targets. Their results showed that disruption of key miRNAs may result in the global aberration of one or more pathways.

Integrated miRNA and mRNA expression analysis can identify the interaction between these molecules as well as the aberrant expression of miRNAs and mRNA. Moreover, new miRNA target genes can be found through the comprehensive study of the expression of miRNA and mRNA coupled with miRNA target prediction software. However, a multitude of interactions between an miRNA and its target mRNAs discovered by expression profiling and prediction software can be identified. For example, a study of inflammatory breast cancer identified 13 miRNAs from 17295 correlated miRNA-mRNA pairs $^{[185]}$. Thus, function validation and luciferase reporter assay were used to confirm the miRNA-mRNA interactions. In another study, combined integrated miRNA and mRNA expression profiling identified 11 differentially expressed miRNAs and 35 known and novel target genes of the key molecules miR-200c, miR-205, and mir-375 ${ }^{[186]}$.

In silico analysis approaches have also been utilized to analyze genome-wide miRNA and mRNA signatures using publically available datasets. For example, Diao et al identified differentially expressed genes between metastatic and non-metastatic osteosarcoma patients using an online dataset and then performed functional enrichment analysis using the DAVID database ${ }^{[172]}$. They discovered 134 upregulated genes enriched in 14 subcategories and most significantly in cytoskeleton organization and 189 downregulated genes. In addition, miR-202 and miR-9 were found to regulate CALD1 and STX1A, which were among the upregulated genes. This interaction might be important for OS metastasis. A similar strategy was applied to the identification of miRNA and mRNA biomarkers in prostate cancer ${ }^{[180]}$. To assist in the data mining of the vast available datasets, different algorithms have been developed to find significant miRNA-mRNA interactions in different cancer types. To discover disease-specific miRNAmRNA correlation and regulatory modular networks between primary prostate cancer (PPC) and metastatic prostate cancer (MPC), Zhang et al used microarray data from prostate tumor samples, calculated miRNA-mRNA Pearson correlations, established miRNA-mRNA matrices and identified miRNAmRNA modules specified in PC subtypes ${ }^{[187]}$. Kim et al proposed a data-driven, hypergraph structural model and constructed higher-order miRNA-mRNA networks from prostate cancer profiles $^{[188]}$. The model is learned by iteration of structure and parameter learning and characterizes relationships within complex miRNA-mRNA modules showing oncogenic or tumor suppression characteristics, which are known to be associated with the properties of primary and metastatic prostate cancer.

An analysis of the miRNA and mRNA expression behavior of a large cohort of breast, lung, ovarian, and prostate carcinoma patients characterized a cancer-specific mRNA signature that can distinguish diseased and healthy patients, and the mRNAs is likely regulated not only by individual
miRNAs but also by networks of miRNAs ${ }^{[189]}$. The miRNA and mRNA cancer signature can be characterized much more easily than drawing the interaction networks of miRNA and mRNA.

\section{Summary and future perspectives}

Genome-wide approaches of microarray analysis and NGS for the profiling of tumor or cancer cell line gene expression have revealed many specific gene signatures related to different cancer types or clinical information (diagnostic, prognostic, or treatment). High-throughput methods provide a fundamental understanding of the biological dynamics of cancer and more accurate diagnosis, prognosis and prediction in therapeutic management. These gene sets could be used as diagnostic or prognostic markers to monitor the risk of tumor progression and to guide therapeutic treatments. Furthermore, the application of miRNAs from plasma, serum, urine and other body fluids as non-invasive biomarkers in different cancer is undergoing rapid development ${ }^{[190]}$. The wide use of miRNA tests in different sample types such as body fluids and FFPE make it more widely applicable than mRNA markers.

Although miRNAs are promising detection and prognosis biomarkers, methodological and technical challenges remain. The variety of methodologies, cancer types, normalization strategies and the difficulties in detecting miRNA in body fluids have led to considerable variability among different platforms and laboratories. For example, the selection of endogenous reference miRNAs in the serum for RT-PCR or validation of miRNA biomarkers is still challenging. RUN6B, which is widely used as a reference gene in tissue and cell samples, is not stably expressed in plasma or serum from different individuals ${ }^{[191]}$, and miR-16 ${ }^{[192]}$ is more frequently used. miR-93 ${ }^{[193]}$, miR-191-5p, and U6 $6^{[194,195]}$ have also been used as reference genes for serum samples. Other protocols, such as absolute quantitation of miRNA levels ${ }^{[196]}$ and identification of input volumes by adding spiked-in miRNA, such as ce-miR-39 ${ }^{[101]}$, are also used. Normalization of miRNA array data usually utilizes the total RNA expression signal ${ }^{[197]}$, while NGS uses the total reads, which is much more stable than one reference gene in RT-PCR.

The gene-expression signatures or panels of miRNA and mRNA may improve diagnostic accuracy, prediction of therapeutic responses and overall survival of patients with cancer. However, miRNA and mRNA signatures cannot independently solve all problems, and combinations of known biomarkers, such as cancer-related antigens, gene mutation and $\mathrm{CNV}$, together with miRNAs and mRNAs will increase the specificity and sensitivity of clinical tests ${ }^{[19]}$. Moreover, larger-scale clinical trials and long-term clinical follow-up are needed to validate the published biomarkers.

We are entering a new era with enormous amounts of data generated by NGS and microarray analysis. In the near future, with the advance of cancer research, more sensitive and specific miRNAs/mRNA signatures may be identified and become more routinely used in cancer detection, diagnostic and prognostic clinical trials. 


\section{References}

1 Bray F, Jemal A, Grey N, Ferlay J, Forman D. Global cancer transitions according to the Human Development Index (2008-2030): a population-based study. Lancet Oncol 2012; 13: 790-801.

2 Cheung HW, Cowley GS, Weir BA, Boehm JS, Rusin S, Scott JA, et al. Systematic investigation of genetic vulnerabilities across cancer cell lines reveals lineage-specific dependencies in ovarian cancer. Proc Natl Acad Sci U S A 2011; 108: 12372-7.

3 Ludwig JA, Weinstein JN. Biomarkers in cancer staging, prognosis and treatment selection. Nat Rev Cancer 2005; 5: 845-56.

4 Lee RC, Feinbaum RL, Ambros V. The C. elegans heterochronic gene lin-4 encodes small RNAs with antisense complementarity to lin-14. Cell 1993; 75: 843-54.

5 Kasinski AL, Slack FJ. Epigenetics and genetics. MicroRNAs en route to the clinic: progress in validating and targeting microRNAs for cancer therapy. Nat Rev Cancer 2011; 11: 849-64.

6 Friedman RC, Farh KK, Burge CB, Bartel DP. Most mammalian mRNAs are conserved targets of microRNAs. Genome Res 2009; 19 : 92-105.

7 Stahlhut C, Slack FJ. MicroRNAs and the cancer phenotype: profiling, signatures and clinical implications. Genome Med 2014; 5: 111.

8 Hayes J, Peruzzi PP, Lawler S. MicroRNAs in cancer: biomarkers, functions and therapy. Trends Mol Med 2014; 20: 460-9.

9 He L, Thomson JM, Hemann MT, Hernando-Monge E, Mu D, Goodson $\mathrm{S}$, et al. A microRNA polycistron as a potential human oncogene. Nature 2005; 435: 828-33.

10 Zhang B, Pan X, Cobb GP, Anderson TA. microRNAs as oncogenes and tumor suppressors. Dev Biol 2007; 302: 1-12.

11 Michael MZ, SM OC, van Holst Pellekaan NG, Young GP, James RJ. Reduced accumulation of specific microRNAs in colorectal neoplasia. Mol Cancer Res 2003; 1: 882-91.

12 Iorio MV, Ferracin M, Liu CG, Veronese A, Spizzo R, Sabbioni S, et al. MicroRNA gene expression deregulation in human breast cancer. Cancer Res 2005; 65: 7065-70.

13 Lu J, Getz G, Miska EA, Alvarez-Saavedra E, Lamb J, Peck D, et al. MicroRNA expression profiles classify human cancers. Nature 2005; 435: 834-8.

14 Yanaihara N, Caplen N, Bowman E, Seike M, Kumamoto K, Yi M, et al. Unique microRNA molecular profiles in lung cancer diagnosis and prognosis. Cancer Cell 2006; 9: 189-98.

15 Wang S, Wang L, Bayaxi N, Li J, Verhaegh W, Janevski A, et al. A microRNA panel to discriminate carcinomas from high-grade intraepithelial neoplasms in colonoscopy biopsy tissue. Gut 2012; 62: 280-9.

16 Volinia S, Calin GA, Liu CG, Ambs S, Cimmino A, Petrocca F, et al. A microRNA expression signature of human solid tumors defines cancer gene targets. Proc Natl Acad Sci U S A 2006; 103: 2257-61.

17 Tetzlaff MT, Liu A, Xu X, Master SR, Baldwin DA, Tobias JW, et al. Differential expression of miRNAs in papillary thyroid carcinoma compared to multinodular goiter using formalin fixed paraffin embedded tissues. Endocr Pathol 2007; 18: 163-73.

18 Zhou J, Yu L, Gao X, Hu J, Wang J, Dai Z, et al. Plasma microRNA panel to diagnose hepatitis $B$ virus-related hepatocellular carcinoma. J Clin Oncol 2011; 29: 4781-8.

19 Liu H, Zhu L, Liu B, Yang L, Meng X, Zhang W, et al. Genome-wide microRNA profiles identify miR-378 as a serum biomarker for early detection of gastric cancer. Cancer Lett 2012; 316: 196-203.

20 Zhang C, Wang C, Chen X, Yang C, Li K, Wang J, et al. Expression profile of microRNAs in serum: a fingerprint for esophageal squamous cell carcinoma. Clin Chem 2010; 56: 1871-9.

21 Chen X, Ba Y, Ma L, Cai X, Yin Y, Wang K, et al. Characterization of microRNAs in serum: a novel class of biomarkers for diagnosis of cancer and other diseases. Cell Res 2008; 18: 997-1006.

22 Liu R, Zhang C, Hu Z, Li G, Wang C, Yang C, et al. A five-microRNA signature identified from genome-wide serum microRNA expression profiling serves as a fingerprint for gastric cancer diagnosis. Eur J Cancer 2011; 47: 784-91.

23 Li LM, Hu ZB, Zhou ZX, Chen X, Liu FY, Zhang JF, et al. Serum microRNA profiles serve as novel biomarkers for HBV infection and diagnosis of HBV-positive hepatocarcinoma. Cancer Res 2010; 70: 9798-807.

24 Farazi TA, Horlings HM, Ten Hoeve JJ, Mihailovic A, Halfwerk H, Morozov $P$, et al. MicroRNA sequence and expression analysis in breast tumors by deep sequencing. Cancer Res 2011; 71: 4443-53.

25 Wu X, Somlo G, Yu Y, Palomares MR, Li AX, Zhou W, et al. De novo sequencing of circulating miRNAs identifies novel markers predicting clinical outcome of locally advanced breast cancer. J Transl Med 2011; 10: 42.

26 Martens-Uzunova ES, Jalava SE, Dits NF, van Leenders GJ, Moller S, Trapman J, et al. Diagnostic and prognostic signatures from the small non-coding RNA transcriptome in prostate cancer. Oncogene 2011; 31: 978-91.

27 Wandt H, Haferlach T, Thiede C, Ehninger G. WHO classification of myeloid neoplasms and leukemia. Blood 2010; 115: 748-9.

28 Cattaneo M, Pelosi E, Castelli G, Cerio AM, A DA, Porretti L, et al. A miRNA signature in human cord blood stem and progenitor cells as potential biomarker of specific acute myeloid leukemia subtypes. J Cell Physiol 2015; 230: 1770-80.

29 Liu C, Kelnar K, Vlassov AV, Brown D, Wang J, Tang DG. Distinct microRNA expression profiles in prostate cancer stem/progenitor cells and tumor-suppressive functions of let-7. Cancer Res 2012; 72 : 3393-404.

30 Qi J, Wang J, Katayama H, Sen S, Liu SM. Circulating microRNAs (cmiRNAs) as novel potential biomarkers for hepatocellular carcinoma. Neoplasma 2012; 60: 135-42.

31 Gilad S, Lithwick-Yanai G, Barshack I, Benjamin S, Krivitsky I, Edmonston TB, et al. Classification of the four main types of lung cancer using a microRNA-based diagnostic assay. J Mol Diagn 2012; 14: 510-7.

32 Xiao B, Guo J, Miao Y, Jiang Z, Huan R, Zhang Y, et al. Detection of miR-106a in gastric carcinoma and its clinical significance. Clin Chim Acta 2009; 400: 97-102.

33 Zhang Y, Guo J, Li D, Xiao B, Miao Y, Jiang Z, et al. Down-regulation of miR-31 expression in gastric cancer tissues and its clinical significance. Med Oncol 2009; 27: 685-9.

34 Valladares-Ayerbes M, Reboredo M, Medina-Villaamil V, IglesiasDiaz P, Lorenzo-Patino MJ, Haz M, et al. Circulating miR-200c as a diagnostic and prognostic biomarker for gastric cancer. J TransI Med 2012; 10: 186.

35 Konishi H, Ichikawa D, Komatsu S, Shiozaki A, Tsujiura M, Takeshita H, et al. Detection of gastric cancer-associated microRNAs on microRNA microarray comparing pre- and post-operative plasma. $\mathrm{Br} J$ Cancer 2012; 106: 740-7.

36 Tsujiura M, Ichikawa D, Komatsu S, Shiozaki A, Takeshita H, Kosuga $\mathrm{T}$, et al. Circulating microRNAs in plasma of patients with gastric cancers. Br J Cancer 2010; 102: 1174-9.

37 Bloomston M, Frankel WL, Petrocca F, Volinia S, Alder H, Hagan JP, et al. MicroRNA expression patterns to differentiate pancreatic adenocarcinoma from normal pancreas and chronic pancreatitis. JAMA 2007; 297: 1901-8.

38 Habbe N, Koorstra JB, Mendell JT, Offerhaus GJ, Ryu JK, Feldmann G, et al. MicroRNA miR-155 is a biomarker of early pancreatic neoplasia. Cancer Biol Ther 2009; 8: 340-6.

39 du Rieu MC, Torrisani J, Selves J, Al Saati T, Souque A, Dufresne M, 
et al. MicroRNA-21 is induced early in pancreatic ductal adenocarcinoma precursor lesions. Clin Chem 2010; 56: 603-12.

40 Ali S, Almhanna K, Chen W, Philip PA, Sarkar FH. Differentially expressed miRNAs in the plasma may provide a molecular signature for aggressive pancreatic cancer. Am J TransI Res 2010; 3: 28-47.

41 Ho AS, Huang X, Cao H, Christman-Skieller C, Bennewith K, Le QT, et al. Circulating miR-210 as a Novel Hypoxia Marker in Pancreatic Cancer. TransI Oncol 2010; 3: 109-13.

42 Wang J. MicroRNAs in plasma of pancreatic ductal adenocarcinoma patients as novel blood-based biomarkers of disease. Cancer Prev Res (Phila) 2009; 2: 807-13.

43 Sempere LF, Christensen M, Silahtaroglu A, Bak M, Heath CV, Schwartz G, et al. Altered MicroRNA expression confined to specific epithelial cell subpopulations in breast cancer. Cancer Res 2007; 67: 11612-20.

44 Hui AB, Shi W, Boutros PC, Miller N, Pintilie M, Fyles T, et al. Robust global micro-RNA profiling with formalin-fixed paraffin-embedded breast cancer tissues. Lab Invest 2009; 89: 597-606.

45 Huang Q, Gumireddy K, Schrier M, le Sage C, Nagel R, Nair S, et al. The microRNAs miR-373 and miR-520c promote tumour invasion and metastasis. Nat Cell Biol 2008; 10: 202-10.

46 Tsang WP, Kwok TT. Let-7a microRNA suppresses therapeuticsinduced cancer cell death by targeting caspase-3. Apoptosis 2008; 13: 1215-22.

47 Yamamoto Y. MicroRNA-500 as a potential diagnostic marker for hepatocellular carcinoma. Biomarkers 2009; 14: 529-38.

48 Meng F. MicroRNA-21 regulates expression of the PTEN tumor suppressor gene in human hepatocellular cancer. Gastroenterology 2007; 133: 647-58.

49 Xu J, Wu C, Che X, Wang L, Yu D, Zhang T, et al. Circulating microRNAs, miR-21, miR-122, and miR-223, in patients with hepatocellular carcinoma or chronic hepatitis. Mol Carcinog 2011; 50: 136-42.

50 Gui J, Tian Y, Wen X, Zhang W, Zhang P, Gao J, et al. Serum microRNA characterization identifies miR-885-5p as a potential marker for detecting liver pathologies. Clin Sci (Lond) 2010; 120: 183-93.

51 Qu KZ, Zhang K, Li H, Afdhal NH, Albitar M. Circulating microRNAs as biomarkers for hepatocellular carcinoma. J Clin Gastroenterol 2011; 45: 355-60.

52 Lebanony D, Benjamin H, Gilad S, Ezagouri M, Dov A, Ashkenazi K, et al. Diagnostic assay based on hsa-miR-205 expression distinguishes squamous from nonsquamous non-small-cell lung carcinoma. J Clin Oncol 2009; 27: 2030-7.

53 Sampson VB, Rong NH, Han J, Yang Q, Aris V, Soteropoulos P, et al. MicroRNA let-7a down-regulates MYC and reverts MYC-induced growth in Burkitt lymphoma cells. Cancer Res 2007; 67: 9762-70.

54 Volinia S. A microRNA expression signature of human solid tumors defines cancer gene targets. Proc Natl Acad Sci USA 2006; 103: 2257-61.

55 Roth C, Kasimir-Bauer S, Pantel K, Schwarzenbach H. Screening for circulating nucleic acids and caspase activity in the peripheral blood as potential diagnostic tools in lung cancer. Mol Oncol 2011; 5: 281-91.

56 Rabinowits G. Exosomal microRNA: a diagnostic marker for lung cancer. Clin Lung Cancer 2009; 10: 42-6.

57 Hatley ME, Patrick DM, Garcia MR, Richardson JA, Bassel-Duby R, van Rooij E, et al. Modulation of K-Ras-dependent lung tumorigenesis by MicroRNA-21. Cancer Cell 2010; 18: 282-93.

58 Silva J, Garcia V, Zaballos A, Provencio M, Lombardia L, Almonacid $\mathrm{L}$, et al. Vesicle-related microRNAs in plasma of nonsmall cell lung cancer patients and correlation with survival. Eur Respir J 2010; 37: 617-23.
59 Shi XB, Xue L, Yang J, Ma AH, Zhao J, Xu M, et al. An androgen-regulated miRNA suppresses Bak1 expression and induces androgenindependent growth of prostate cancer cells. Proc Natl Acad Sci U S A 2007; 104: 19983-8.

60 Bonci D, Coppola V, Musumeci M, Addario A, Giuffrida R, Memeo L, et al. The miR-15a-miR-16-1 cluster controls prostate cancer by targeting multiple oncogenic activities. Nat Med 2008; 14: 1271-7.

61 Lin SL, Chiang A, Chang D, Ying SY. Loss of mir-146a function in hormone-refractory prostate cancer. RNA 2008; 14: 417-24.

62 Saini S, Majid S, Yamamura S, Tabatabai L, Suh So, Shahryari V, et al. Regulatory Role of mir-203 in Prostate Cancer Progression and Metastasis. Clin Cancer Res 2010; 17: 5287-98.

63 Hagman Z, Larne O, Edsjo A, Bjartell A, Ehrnstrom RA, Ulmert D, et al. miR-34c is downregulated in prostate cancer and exerts tumor suppressive functions. Int J Cancer 2011; 127: 2768-76.

64 Johnson SM, Grosshans H, Shingara J, Byrom M, Jarvis R, Cheng A, et al. RAS is regulated by the let-7 microRNA family. Cell 2005; 120 : 635-47.

65 Calin GA, Dumitru CD, Shimizu M, Bichi R, Zupo S, Noch E, et al. Frequent deletions and down-regulation of micro- RNA genes miR15 and miR16 at 13q14 in chronic lymphocytic leukemia. Proc Natl Acad Sci U S A 2002; 99: 15524-9.

66 Calin GA, Cimmino A, Fabbri M, Ferracin M, Wojcik SE, Shimizu M, et al. MiR-15a and miR-16-1 cluster functions in human leukemia. Proc Natl Acad Sci U S A 2008; 105: 5166-71.

67 Cimmino A, Calin GA, Fabbri M, lorio MV, Ferracin M, Shimizu M, et al. miR-15 and miR-16 induce apoptosis by targeting BCL2. Proc Natl Acad Sci U S A 2005; 102: 13944-9.

68 Hsieh IS, Chang KC, Tsai YT, Ke JY, Lu PJ, Lee KH, et al. MicroRNA-320 suppresses the stem cell-like characteristics of prostate cancer cells by downregulating the Wnt/beta-catenin signaling pathway. Carcinogenesis 2012; 34: 530-8.

69 Lodes MJ, Caraballo M, Suciu D, Munro S, Kumar A, Anderson B. Detection of cancer with serum miRNAs on an oligonucleotide microarray. PLoS ONE 2009; 4: e6229.

70 Moltzahn F, Olshen AB, Baehner L, Peek A, Fong L, Stoppler H, et al. Microfluidic-based multiplex qRT-PCR identifies diagnostic and prognostic microRNA signatures in the sera of prostate cancer patients. Cancer Res 2010; 71: 550-60.

71 Brase JC, Johannes M, Schlomm T, Falth M, Haese A, Steuber T, et al. Circulating miRNAs are correlated with tumor progression in prostate cancer. Int J Cancer 2010; 128: 608-16.

72 Yaman Agaoglu F, Kovancilar M, Dizdar Y, Darendeliler E, Holdenrieder S, Dalay N, et al. Investigation of miR-21, miR-141, and miR-221 in blood circulation of patients with prostate cancer. Tumour Biol 2011; 32: 583-8.

73 Schetter AJ. MicroRNA expression profiles associated with prognosis and therapeutic outcome in colon adenocarcinoma. JAMA 2008; 299: 425-36.

74 Coulouarn C, Factor VM, Andersen JB, Durkin ME, Thorgeirsson SS. Loss of miR-122 expression in liver cancer correlates with suppression of the hepatic phenotype and gain of metastatic properties. Oncogene 2009; 28: 3526-36.

75 Takamizawa J. Reduced expression of the let-7 microRNAs in human lung cancers in association with shortened postoperative survival. Cancer Res 2004; 64: 3753-6.

76 Tavazoie SF, Alarcon C, Oskarsson T, Padua D, Wang Q, Bos PD, et al. Endogenous human microRNAs that suppress breast cancer metastasis. Nature 2008; 451: 147-52.

77 Valladares-Ayerbes M, Blanco M, Haz M, Medina V, Iglesias-Diaz P, Lorenzo-Patino MJ, et al. Prognostic impact of disseminated tumor 
cells and microRNA-17-92 cluster deregulation in gastrointestinal cancer. Int J Oncol 2011; 39: 1253-64.

78 Li X, Zhang Y, Ding J, Wu K, Fan D. Survival prediction of gastric cancer by a seven-microRNA signature. Gut 2009; 59: 579-85.

79 Zhang X, Yan Z, Zhang J, Gong L, Li W, Cui J, et al. Combination of hsa-miR-375 and hsa-miR-142-5p as a predictor for recurrence risk in gastric cancer patients following surgical resection. Ann Oncol 2011; 22: 2257-66.

$80 \mathrm{Yu}$ J, Ohuchida K, Mizumoto K, Sato N, Kayashima T, Fujita H, et al. MicroRNA, hsa-miR-200c, is an independent prognostic factor in pancreatic cancer and its upregulation inhibits pancreatic cancer invasion but increases cell proliferation. Mol Cancer 2010; 9: 169.

81 Kong X, Du Y, Wang G, Gao J, Gong Y, Li L, et al. Detection of differentially expressed microRNAs in serum of pancreatic ductal adenocarcinoma patients: miR-196a could be a potential marker for poor prognosis. Dig Dis Sci 2010; 56: 602-9.

82 Tavazoie SF. Endogenous human microRNAs that suppress breast cancer metastasis. Nature 2008; 451: 147-52.

83 Valastyan S, Reinhardt F, Benaich N, Calogrias D, Szasz AM, Wang ZC, et al. A pleiotropically acting microRNA, miR-31, inhibits breast cancer metastasis. Cell 2009; 137: 1032-46.

84 Yan LX, Huang XF, Shao Q, Huang MY, Deng L, Wu QL, et al. MicroRNA miR-21 overexpression in human breast cancer is associated with advanced clinical stage, lymph node metastasis and patient poor prognosis. RNA 2008; 14: 2348-60.

85 Zhao H, Shen J, Medico L, Wang D, Ambrosone CB, Liu S. A pilot study of circulating miRNAs as potential biomarkers of early stage breast cancer. PLoS ONE 2010; 5: e13735.

86 Roth C, Rack B, Muller V, Janni W, Pantel K, Schwarzenbach H. Circulating microRNAs as blood-based markers for patients with primary and metastatic breast cancer. Breast Cancer Res 2010; 12: R90.

87 Chang TC, Wentzel EA, Kent OA, Ramachandran K, Mullendore M, Lee $\mathrm{KH}$, et al. Transactivation of miR-34a by p53 broadly influences gene expression and promotes apoptosis. Mol Cell 2007; 26: 745-52.

88 He L, He X, Lim LP, de Stanchina E, Xuan Z, Liang Y, et al. A microRNA component of the p53 tumour suppressor network. Nature 2007; 447: 1130-4.

89 Malek SN. The biology and clinical significance of acquired genomic copy number aberrations and recurrent gene mutations in chronic lymphocytic leukemia. Oncogene 2012; 32: 2805-17.

90 Asaga S, Kuo C, Nguyen T, Terpenning M, Giuliano AE, Hoon DS. Direct serum assay for microRNA-21 concentrations in early and advanced breast cancer. Clin Chem 2010; 57: 84-91.

91 Heneghan HM, Miller N, Kelly R, Newell J, Kerin MJ. Systemic miRNA-195 differentiates breast cancer from other malignancies and is a potential biomarker for detecting noninvasive and early stage disease. Oncologist 2010; 15: 673-82.

92 Navarro A, Diaz T, Gallardo E, Vinolas N, Marrades RM, Gel B, et al. Prognostic implications of miR-16 expression levels in resected nonsmall-cell lung cancer. J Surg Oncol 2011; 103: 411-5.

93 Hu Z, Chen X, Zhao Y, Tian T, Jin G, Shu Y, et al. Serum microRNA signatures identified in a genome-wide serum microRNA expression profiling predict survival of non-small-cell lung cancer. J Clin Oncol 2010; 28: 1721-6.

$94 \mathrm{Hu}$ X, Schwarz JK, Lewis JS Jr, Huettner PC, Rader JS, Deasy JO, et al. A microRNA expression signature for cervical cancer prognosis. Cancer Res 2010; 70: 1441-8.

95 Laios A, O'Toole S, Flavin R, Martin C, Kelly L, Ring M, et al. Potential role of miR-9 and miR-223 in recurrent ovarian cancer. Mol Cancer 2008; 7: 35.

96 Hu X, Macdonald DM, Huettner PC, Feng Z, EI Naqa IM, Schwarz JK, et al. A miR-200 microRNA cluster as prognostic marker in advanced ovarian cancer. Gynecol Oncol 2009; 114: 457-64.

97 Eitan R, Kushnir M, Lithwick-Yanai G, David MB, Hoshen M, Glezerman $\mathrm{M}$, et al. Tumor microRNA expression patterns associated with resistance to platinum based chemotherapy and survival in ovarian cancer patients. Gynecol Oncol 2009; 114: 253-9.

98 Flavin R, Smyth P, Barrett C, Russell S, Wen H, Wei J, et al. miR-29b expression is associated with disease-free survival in patients with ovarian serous carcinoma. Int J Gynecol Cancer 2009; 19: 641-7.

99 Taylor DD, Gercel-Taylor C. MicroRNA signatures of tumor-derived exosomes as diagnostic biomarkers of ovarian cancer. Gynecol Oncol 2008; 110: 13-21.

100 Spahn M, Kneitz S, Scholz CJ, Stenger N, Rudiger T, Strobel P, et al. Expression of microRNA-221 is progressively reduced in aggressive prostate cancer and metastasis and predicts clinical recurrence. Int J Cancer 2009; 127: 394-403.

101 Mitchell PS, Parkin RK, Kroh EM, Fritz BR, Wyman SK, PogosovaAgadjanyan EL, et al. Circulating microRNAs as stable blood-based markers for cancer detection. Proc Natl Acad Sci U S A 2008; 105 : 10513-8.

102 Zhang HL, Yang LF, Zhu Y, Yao XD, Zhang SL, Dai B, et al. Serum miRNA-21: elevated levels in patients with metastatic hormonerefractory prostate cancer and potential predictive factor for the efficacy of docetaxel-based chemotherapy. Prostate 2010; 71: 326-31.

103 Liu C, Kelnar K, Liu B, Chen X, Calhoun-Davis T, Li H, et al. The microRNA miR-34a inhibits prostate cancer stem cells and metastasis by directly repressing CD44. Nat Med 2011; 17: 211-5.

104 Png KJ, Halberg N, Yoshida M, Tavazoie SF. A microRNA regulon that mediates endothelial recruitment and metastasis by cancer cells. Nature 2011; 481: 190-4.

105 Zhan X, Wu W, Han B, Gao G, Qiao R, Lv J, et al. Hsa-miR-196a2 functional SNP is associated with severe toxicity after platinum-based chemotherapy of advanced nonsmall cell lung cancer patients in a Chinese population. J Clin Lab Anal 2012; 26: 441-6.

106 Zhang G, Zong J, Lin S, Verhoeven RJ, Tong S, Chen Y, et al. Circulating Epstein-Barr virus microRNAs miR-BART7 and miR-BART13 as biomarkers for nasopharyngeal carcinoma diagnosis and treatment. Int J Cancer 2015; 136: E301-12.

107 Molina-Pinelo S, Carnero A, Rivera F, Estevez-Garcia P, Bozada JM, Limon ML, et al. MiR-107 and miR-99a-3p predict chemotherapy response in patients with advanced colorectal cancer. BMC Cancer 2014; 14: 656.

108 Saito M, Shiraishi K, Matsumoto K, Schetter AJ, Ogata-Kawata H, Tsuchiya N, et al. A three-microRNA signature predicts responses to platinum-based doublet chemotherapy in patients with lung adenocarcinoma. Clin Cancer Res 2014; 20: 4784-93.

109 Boise LH, Gonzalez-Garcia M, Postema CE, Ding L, Lindsten T, Turka $\mathrm{LA}$, et al. bcl-x, a bcl-2-related gene that functions as a dominant regulator of apoptotic cell death. Cell 1993; 74: 597-608.

110 Golub TR, Slonim DK, Tamayo P, Huard C, Gaasenbeek M, Mesirov $J P$, et al. Molecular classification of cancer: class discovery and class prediction by gene expression monitoring. Science 1999; 286 : 531-7.

111 Botling J, Edlund K, Lohr M, Hellwig B, Holmberg L, Lambe M, et al. Biomarker discovery in non-small cell lung cancer: integrating gene expression profiling, meta-analysis, and tissue microarray validation. Clin Cancer Res 2013; 19: 194-204.

112 Hippo Y, Taniguchi H, Tsutsumi S, Machida N, Chong JM, Fukayama M, et al. Global gene expression analysis of gastric cancer by oligonucleotide microarrays. Cancer Res 2002; 62: 233-40.

113 Bull JH, Ellison G, Patel A, Muir G, Walker M, Underwood M, et al. 
Identification of potential diagnostic markers of prostate cancer and prostatic intraepithelial neoplasia using cDNA microarray. Br J Cancer 2001; 84: 1512-9.

114 Kupryjanczyk J, Szymanska T, Madry R, Timorek A, Stelmachow J, Karpinska G, et al. Evaluation of clinical significance of TP53, BCL2, BAX and MEK1 expression in 229 ovarian carcinomas treated with platinum-based regimen. Br J Cancer 2003; 88: 848-54.

115 Nielsen JS, Jakobsen E, Holund B, Bertelsen K, Jakobsen A. Prognostic significance of p53, Her-2, and EGFR overexpression in borderline and epithelial ovarian cancer. Int J Gynecol Cancer 2004; 14: 108696.

116 Hou T, Yang C, Tong C, Zhang H, Xiao J, Li J. Overexpression of ASAP1 is associated with poor prognosis in epithelial ovarian cancer. Int J Clin Exp Pathol 2013; 7: 280-7.

117 Brodsky AS, Fischer A, Miller DH, Vang S, MacLaughlan S, Wu HT, et al. Expression profiling of primary and metastatic ovarian tumors reveals differences indicative of aggressive disease. PLoS One 2014; 9 : e94476.

118 Bellodi-Privato M, Kubrusly MS, Stefano JT, Soares IC, Wakamatsu A, Oliveira AC, et al. Differential gene expression profiles of hepatocellular carcinomas associated or not with viral infection. Braz J Med Biol Res 2009; 42: 119-27.

119 Hicks GG, Singh N, Nashabi A, Mai S, Bozek G, Klewes L, et al. Fus deficiency in mice results in defective B-lymphocyte development and activation, high levels of chromosomal instability and perinatal death. Nat Genet 2000; 24: 175-9.

120 Virtaneva K, Wright FA, Tanner SM, Yuan B, Lemon WJ, Caligiuri MA, et al. Expression profiling reveals fundamental biological differences in acute myeloid leukemia with isolated trisomy 8 and normal cytogenetics. Proc Natl Acad Sci U S A 2001; 98: 1124-9.

121 Taskesen E, Staal FJ, Reinders MJ. An integrated approach of gene expression and DNA-methylation profiles of WNT signaling genes uncovers novel prognostic markers in acute myeloid leukemia. BMC Bioinformatics 2015; 16: S4.

122 DeFatta RJ, Turbat-Herrera EA, Li BD, Anderson W, De Benedetti A. Elevated expression of elF4E in confined early breast cancer lesions: possible role of hypoxia. Int J Cancer 1999; 80: 516-22.

123 Nathan CO, Amirghahari N, Abreo F, Rong X, Caldito G, Jones ML, et al. Overexpressed elF4E is functionally active in surgical margins of head and neck cancer patients via activation of the Akt/mammalian target of rapamycin pathway. Clin Cancer Res 2004; 10: 5820-7.

124 Berkel HJ, Turbat-Herrera EA, Shi R, de Benedetti A. Expression of the translation initiation factor elF4E in the polyp-cancer sequence in the colon. Cancer Epidemiol Biomarkers Prev 2001; 10: 663-6.

125 Matthews-Greer J, Caldito G, de Benedetti A, Herrera GA, DominguezMalagon $\mathrm{H}$, Chanona-Vilchis J, et al. elF4E as a marker for cervical neoplasia. Appl Immunohistochem Mol Morphol 2005; 13: 367-70.

126 Graff JR, Konicek BW, Lynch RL, Dumstorf CA, Dowless MS, McNulty $\mathrm{AM}$, et al. elF4E activation is commonly elevated in advanced human prostate cancers and significantly related to reduced patient survival. Cancer Res 2009; 69: 3866-73.

127 Ghigna C, Valacca C, Biamonti G. Alternative splicing and tumor progression. Curr Genomics 2008; 9: 556-70.

128 Mazoyer S, Puget N, Perrin-Vidoz L, Lynch HT, Serova-Sinilnikova OM, Lenoir GM. A BRCA1 nonsense mutation causes exon skipping. Am J Hum Genet 1998; 62: 713-5.

129 de Miguel FJ, Sharma RD, Pajares MJ, Montuenga LM, Rubio A, Pio R. Identification of alternative splicing events regulated by the oncogenic factor SRSF1 in lung cancer. Cancer Res 2013; 74: 1105-15.

130 Bemmo A, Dias C, Rose AA, Russo C, Siegel P, Majewski J. Exonlevel transcriptome profiling in murine breast cancer reveals splicing changes specific to tumors with different metastatic abilities. PLoS One 2010; 5: e11981.

131 Lapuk A, Marr H, Jakkula L, Pedro H, Bhattacharya S, Purdom E, et al. Exon-level microarray analyses identify alternative splicing programs in breast cancer. Mol Cancer Res 2010; 8: 961-74.

132 Perou CM, Sorlie T, Eisen MB, van de Rijn M, Jeffrey SS, Rees CA, et al. Molecular portraits of human breast tumours. Nature 2000; 406: 747-52.

133 Karlsson E, Delle U, Danielsson A, Olsson B, Abel F, Karlsson P, et al. Gene expression variation to predict 10-year survival in lymph-nodenegative breast cancer. BMC Cancer 2008; 8: 254.

$134 \mathrm{Li} \mathrm{Z,} \mathrm{Zhang} \mathrm{W,} \mathrm{Wu} \mathrm{M,} \mathrm{Zhu} \mathrm{S,} \mathrm{Gao} \mathrm{C,} \mathrm{Sun} \mathrm{L,} \mathrm{et} \mathrm{al.} \mathrm{Gene} \mathrm{expression-}$ based classification and regulatory networks of pediatric acute lymphoblastic leukemia. Blood 2009; 114: 4486-93.

135 Salazar R, Roepman P, Capella G, Moreno V, Simon I, Dreezen C, et al. Gene expression signature to improve prognosis prediction of stage II and III colorectal cancer. J Clin Oncol 2010; 29: 17-24.

136 Dvinge H, Git A, Graf S, Salmon-Divon M, Curtis C, Sottoriva A, et al. The shaping and functional consequences of the microRNA landscape in breast cancer. Nature 2013; 497: 378-82.

137 Lin KT, Shann YJ, Chau GY, Hsu CN, Huang CY. Identification of latent biomarkers in hepatocellular carcinoma by ultra-deep wholetranscriptome sequencing. Oncogene 2014; 33: 4786-94.

138 Wu Y, Wang X, Wu F, Huang R, Xue F, Liang G, et al. Transcriptome profiling of the cancer, adjacent non-tumor and distant normal tissues from a colorectal cancer patient by deep sequencing. PLoS One 2012; 7: e41001.

139 Xiao W, Tran B, Staudt LM, Schmitz R. High-throughput RNA sequencing in B-cell lymphomas. Methods Mol Biol 2013; 971: 295-312.

140 Kunz M, Dannemann M, Kelso J. High-throughput sequencing of the melanoma genome. Exp Dermatol 2013; 22: 10-7.

141 Berger MF, Levin JZ, Vijayendran K, Sivachenko A, Adiconis X, Maguire J, et al. Integrative analysis of the melanoma transcriptome. Genome Res 2010; 20: 413-27.

142 Kalari KR, Rossell D, Necela BM, Asmann YW, Nair A, Baheti S, et al. Deep sequence analysis of non-small cell lung cancer: integrated analysis of gene expression, alternative splicing, and single nucleotide variations in lung adenocarcinomas with and without oncogenic KRAS mutations. Front Oncol 2012; 2: 12.

143 De Sousa EMF, Wang X, Jansen M, Fessler E, Trinh A, de Rooij LP, et al. Poor-prognosis colon cancer is defined by a molecularly distinct subtype and develops from serrated precursor lesions. Nat Med 2013; 19: 614-8.

144 Sadanandam A, Lyssiotis CA, Homicsko K, Collisson EA, Gibb WJ, WulIschleger $\mathrm{S}$, et al. A colorectal cancer classification system that associates cellular phenotype and responses to therapy. Nat Med 2013; 19: 619-25.

145 Spentzos D, Levine DA, Ramoni MF, Joseph M, Gu X, Boyd J, et al. Gene expression signature with independent prognostic significance in epithelial ovarian cancer. J Clin Oncol 2004; 22: 4700-10.

146 Wang P, Song L, Ge H, Jin P, Jiang Y, Hu W, et al. Crenolanib, a PDGFR inhibitor, suppresses lung cancer cell proliferation and inhibits tumor growth in vivo. Onco Targets Ther 2014; 7: 1761-8.

147 Heldin $\mathrm{CH}$. Targeting the PDGF signaling pathway in tumor treatment. Cell Commun Signal 2013; 11: 97.

148 Kridel R, Meissner B, Rogic S, Boyle M, Telenius A, Woolcock B, et al. Whole transcriptome sequencing reveals recurrent NOTCH1 mutations in mantle cell lymphoma. Blood 2012; 119: 1963-71.

149 Brodtkorb M, Lingjaerde OC, Huse K, Troen G, Hystad M, Hilden VI, et al. Whole-genome integrative analysis reveals expression signatures predicting transformation in follicular lymphoma. Blood 2014; 123 : 
1051-4.

150 Feuer EJ, Wun LM, Boring CC, Flanders WD, Timmel MJ, Tong T. The lifetime risk of developing breast cancer. J Natl Cancer Inst 1993; 85: 892-7.

151 Jemal A, Bray F, Center MM, Ferlay J, Ward E, Forman D. Global cancer statistics. CA Cancer J Clin 2011; 61: 69-90.

152 van de Vijver MJ, He YD, van't Veer LJ, Dai H, Hart AA, Voskuil DW, et al. A gene-expression signature as a predictor of survival in breast cancer. N Engl J Med 2002; 347: 1999-2009.

153 van 't Veer L, Dai H, van de Vijver MJ, He YD, Hart AA, Mao M, et al. Gene expression profiling predicts clinical outcome of breast cancer. Nature 2002; 415: 530-6.

154 Paik S, Shak S, Tang G, Kim C, Baker J, Cronin M, et al. A multigene assay to predict recurrence of tamoxifen-treated, node-negative breast cancer. N Engl J Med 2004; 351: 2817-26.

155 Azim HA Jr, Michiels S, Zagouri F, Delaloge S, Filipits M, Namer M, et al. Utility of prognostic genomic tests in breast cancer practice: The IMPAKT 2012 Working Group Consensus Statement. Ann Oncol 2013; 24: 647-54.

156 O'Connell MJ, Lavery I, Yothers G, Paik S, Clark-Langone KM, Lopatin $\mathrm{M}$, et al. Relationship between tumor gene expression and recurrence in four independent studies of patients with stage II/III colon cancer treated with surgery alone or surgery plus adjuvant fluorouracil plus leucovorin. J Clin Oncol 2010; 28: 3937-44.

157 Salazar R, Roepman P, Capella G, Moreno V, Simon I, Dreezen C, et al. Gene expression signature to improve prognosis prediction of stage II and III colorectal cancer. J Clin Oncol 2011; 29: 17-24.

158 Maak M, Simon I, Nitsche U, Roepman P, Snel M, Glas AM, et al. Independent validation of a prognostic genomic signature (ColoPrint) for patients with stage II colon cancer. Ann Surg 2013; 257: 10538.

159 Marshall KW, Mohr S, Khettabi FE, Nossova N, Chao S, Bao W, et al. A blood-based biomarker panel for stratifying current risk for colorectal cancer. Int J Cancer 2010; 126: 1177-86.

160 Perez-Villamil B, Romera-Lopez A, Hernandez-Prieto S, Lopez-Campos G, Calles A, Lopez-Asenjo JA, et al. Colon cancer molecular subtypes identified by expression profiling and associated to stroma, mucinous type and different clinical behavior. BMC Cancer 2012; 12: 260.

161 Marisa L, de Reynies A, Duval A, Selves J, Gaub MP, Vescovo L, et al. Gene expression classification of colon cancer into molecular subtypes: characterization, validation, and prognostic value. PLoS Med 2013; 10: e1001453.

162 Glinsky GV, Berezovska O, Glinskii AB. Microarray analysis identifies a death-from-cancer signature predicting therapy failure in patients with multiple types of cancer. J Clin Invest 2005; 115: 1503-21.

163 Liu R, Wang X, Chen GY, Dalerba P, Gurney A, Hoey T, et al. The prognostic role of a gene signature from tumorigenic breast-cancer cells. N Engl J Med 2007; 356: 217-26.

164 Wu XM, Shao XQ, Meng XX, Zhang XN, Zhu L, Liu SX, et al. Genomewide analysis of microRNA and mRNA expression signatures in hydroxycamptothecin-resistant gastric cancer cells. Acta Pharmacol Sin 2011; 32: 259-69.

165 Chan JK, Kiet TK, Blansit K, Ramasubbaiah R, Hilton JF, Kapp DS, et al. MiR-378 as a biomarker for response to anti-angiogenic treatment in ovarian cancer. Gynecol Oncol 2014; 133: 568-74.

166 Quitadamo A, Tian L, Hall B, Shi X. An integrated network of microRNA and gene expression in ovarian cancer. BMC Bioinformatics 2015; 16: S5.

167 Cava C, Bertoli G, Ripamonti M, Mauri G, Zoppis I, Della Rosa PA, et al. Integration of mRNA expression profile, copy number alterations, and microRNA expression levels in breast cancer to improve grade definition. PLoS One 2014; 9: e97681.

168 Sieuwerts AM, Mostert B, Bolt-de Vries J, Peeters D, de Jongh FE, Stouthard JM, et al. mRNA and microRNA expression profiles in circulating tumor cells and primary tumors of metastatic breast cancer patients. Clin Cancer Res 2011; 17: 3600-18.

169 Zhong L, Zhu K, Jin N, Wu D, Zhang J, Guo B, et al. A systematic analysis of miRNA-mRNA paired variations reveals widespread miRNA misregulation in breast cancer. Biomed Res Int 2014; 2014: 291280.

170 Bleckmann A, Leha A, Artmann S, Menck K, Salinas-Riester G, Binder $\mathrm{C}$, et al. Integrated miRNA and mRNA profiling of tumor-educated macrophages identifies prognostic subgroups in estrogen receptorpositive breast cancer. Mol Oncol 2015; 9: 155-66.

171 Dai X, Chen A, Bai Z. Integrative investigation on breast cancer in ER, PR and HER2-defined subgroups using mRNA and miRNA expression profiling. Sci Rep 2014; 4: 6566.

172 Diao CY, Guo HB, Ouyang YR, Zhang HC, Liu LH, Bu J, et al. Screening for metastatic osteosarcoma biomarkers with a DNA microarray. Asian Pac J Cancer Prev 2014; 15: 1817-22.

173 Liu N, Liu X, Zhou N, Wu Q, Zhou L, Li Q. Gene expression profiling and bioinformatics analysis of gastric carcinoma. Exp Mol Pathol 2014; 96: 361-6.

174 Liu J, Xue H, Zhang J, Suo T, Xiang Y, Zhang W, et al. MicroRNA-144 inhibits the metastasis of gastric cancer by targeting MET expression. J Exp Clin Cancer Res 2015; 34: 35.

175 Shen Y, Pan Y, Xu L, Chen L, Liu L, Chen H, et al. Identifying microRNA-mRNA regulatory network in gemcitabine-resistant cells derived from human pancreatic cancer cells. Tumour Biol 2015 ; 36: 452534.

176 Huang WC, Chan SH, Jang TH, Chang JW, Ko YC, Yen TC, et al. miRNA-491-5p and GIT1 serve as modulators and biomarkers for oral squamous cell carcinoma invasion and metastasis. Cancer Res 2014; 74: 751-64.

177 Barh D, Jain N, Tiwari S, Field JK, Padin-Iruegas E, Ruibal A, et al. A novel in silico reverse-transcriptomics-based identification and bloodbased validation of a panel of sub-type specific biomarkers in lung cancer. BMC Genomics 2013; 14: S5.

178 Ma R, Wang C, Wang J, Wang D, Xu J. miRNA-mRNA interaction network in non-small-cell lung cancer. Interdiscip Sci. 2015 Apr 11 [Epub ahead of print].

179 Huang T, Yang J, Cai YD. Novel candidate key drivers in the integrative network of genes, microRNAs, methylations, and copy number variations in squamous cell lung carcinoma. Biomed Res Int 2015; 2015: 358125.

180 Feng J, Huang C, Diao X, Fan M, Wang P, Xiao Y, et al. Screening biomarkers of prostate cancer by integrating microRNA and mRNA microarrays. Genet Test Mol Biomarkers 2013; 17: 807-13.

181 Zhang W, Zang J, Jing X, Sun Z, Yan W, Yang D, et al. Identification of candidate miRNA biomarkers from miRNA regulatory network with application to prostate cancer. J TransI Med 2014; 12: 66.

182 Jacques C, Guillotin D, Fontaine JF, Franc B, Mirebeau-Prunier D, Fleury A, et al. DNA microarray and miRNA analyses reinforce the classification of follicular thyroid tumors. J Clin Endocrinol Metab 2013; 98: E981-9.

183 Venkatesan N, Deepa P, Vasudevan M, Khetan V, Reddy AM, Krishnakumar $\mathrm{S}$. Integrated analysis of dysregulated miRNA-gene expression in HMGA2-silenced retinoblastoma cells. Bioinform Biol Insights 2014; 8: 177-91.

$184 \mathrm{Li} \mathrm{X}$, Chen J, Hu X, Huang Y, Li Z, Zhou L, et al. Comparative mRNA and microRNA expression profiling of three genitourinary cancers reveals common hallmarks and cancer-specific molecular events. PLoS 
ONE 2011; 6: e22570.

185 Van der Auwera I, Limame R, van Dam P, Vermeulen PB, Dirix LY, Van Laere SJ. Integrated miRNA and mRNA expression profiling of the inflammatory breast cancer subtype. Br J Cancer 2010; 103: 532-41.

186 Luo D, Wilson JM, Harvel N, Liu J, Pei L, Huang S, et al. A systematic evaluation of miRNA:mRNA interactions involved in the migration and invasion of breast cancer cells. J Transl Med 2013; 11: 57.

187 Zhang W, Edwards A, Fan W, Flemington EK, Zhang K. miRNA-mRNA correlation-network modules in human prostate cancer and the differences between primary and metastatic tumor subtypes. PLoS One 2014; 7: e40130.

$188 \mathrm{Kim}$ SJ, Ha JW, Zhang BT. Constructing higher-order miRNA-mRNA interaction networks in prostate cancer via hypergraph-based learning. BMC Syst Biol 2013; 7: 47.

189 Zadran S, Remacle F, Levine RD. miRNA and mRNA cancer signatures determined by analysis of expression levels in large cohorts of patients. Proc Natl Acad Sci U S A 2013; 110: 19160-5.

190 Schwarzenbach H, Nishida N, Calin GA, Pantel K. Clinical relevance of circulating cell-free microRNAs in cancer. Nat Rev Clin Oncol 2014; 11: 145-56.

191 Ng EK, Chong WW, Jin H, Lam EK, Shin VY, Yu J, et al. Differential expression of microRNAs in plasma of patients with colorectal cancer: a potential marker for colorectal cancer screening. Gut 2009; 58:
1375-81.

192 Wong TS, Liu XB, Wong BY, Ng RW, Yuen AP, Wei WI. Mature miR184 as potential oncogenic microRNA of squamous cell carcinoma of tongue. Clin Cancer Res 2008; 14: 2588-92.

193 Song J, Bai Z, Han W, Zhang J, Meng H, Bi J, et al. Identification of suitable reference genes for qPCR analysis of serum microRNA in gastric cancer patients. Dig Dis Sci 2012; 57: 897-904.

194 Zheng G, Wang H, Zhang X, Yang Y, Wang L, Du L, et al. Identification and validation of reference genes for qPCR detection of serum microRNAs in colorectal adenocarcinoma patients. PLoS One 2013; 8: e83025.

195 Liu SS, Wang YS, Sun YF, Miao LX, Wang J, Li YS, et al. Plasma microRNA-320, microRNA-let-7e and microRNA-21 as novel potential biomarkers for the detection of retinoblastoma. Biomed Rep 2014; 2 : 424-8.

196 Komatsu S, Ichikawa D, Hirajima S, Kawaguchi T, Miyamae M, Okajima W, et al. Plasma microRNA profiles: identification of miR-25 as a novel diagnostic and monitoring biomarker in oesophageal squamous cell carcinoma. Br J Cancer 2014; 111: 1614-24.

197 Pradervand S, Weber J, Thomas J, Bueno M, Wirapati P, Lefort K, et al. Impact of normalization on miRNA microarray expression profiling. RNA 2009; 15: 493-501. 